\title{
Investigation of $T G$ gene variants and their effects on growth, carcass composition, and meat quality traits in Chinese steers
}

\author{
L.P. Zhang ${ }^{1}$, Q.F. Gan ${ }^{2}$, G.Y. Hou ${ }^{3}$, H.J. Gao ${ }^{1}$, J.Y. Li ${ }^{1}$ and S.Z. Xu ${ }^{1}$
}

${ }^{1}$ Key Laboratory for Farm Animal Genetic Resources and Utilization of Ministry of Agriculture of China, Institute of Animal Science, Chinese Academy of Agricultural Sciences, Beijing, China

${ }^{2}$ College of Animal Science, Fujian Agricultural and Forestry University, Fuzhou, Fujian, China ${ }^{3}$ Institute of Tropical Crop Genetic Resources, Chinese Academy of Tropical Agricultural Sciences, Danzhou, Hainan, China

Corresponding author: J.Y. Li

E-mail: JL1@iascaas.net.cn

Genet. Mol. Res. 14 (2): 5320-5326 (2015)

Received April 15, 2014

Accepted March 7, 2015

Published May 22, 2015

DOI http://dx.doi.org/10.4238/2015.May.22.2

\begin{abstract}
Thyroid hormones play an important role in regulating metabolism and can affect metabolism-related traits such as fat deposition. The thyroglobulin $(T G)$ gene produces the precursor of thyroid hormones and has been proposed as a candidate gene for a quantitative trait locus with an effect on fat deposition. In this study, we identified 4 novel single nucleotide polymorphisms (SNPs) in the $5^{\prime}$ flanking region of the $T G$ gene using a DNA sequencing method. The SNP marker association analysis indicated that the T1355C SNPs were significantly associated with meat percentage $(\mathrm{P}<0.05)$. A significant association between the G1356A polymorphism and live weight and loin muscle area was also detected $(\mathrm{P}<0.05)$. However, no significant association was found between 4 SNPs and the other growth, carcass composition, and meat quality traits including intramuscular fat. The results of this study suggest
\end{abstract}


that $T G$ gene-specific SNPs may be a useful marker for growth traits in marker-assisted selection programs in beef cattle.

Key words: Cattle; Thyroglobulin gene; Polymorphism; Growth trait; Carcass composition trait; Meat quality trait

\section{INTRODUCTION}

Thyroid hormones triiodothyronine and thyroxin play a crucial role in metabolism regulation and have effects on adipocyte growth, differentiation, and homeostasis of fat depots (Ailhaud et al., 1992; Darimont et al., 1993; Smas and Sul, 1995; Casas et al., 2005). Thyroglobulin (TG) is the precursor of thyroid hormones and is synthesized from the thyroid follicular cell (Ailhaud et al., 1992). The $T G$ gene has been mapped to a quantitative trait locus (QTL) and is considered as a functional and positional candidate of fat thickness, United States Department of Agriculture (USDA) yield grade, post-weaning average daily gain, birth weight, and weaning weight traits (Casas et al., 2003; Thaller et al., 2003; Kneeland et al., 2004; Maltecca et al., 2009; McClure et al., 2010). Because of the important role of the 5 '-flanking region in regulating gene transcription, the TG5 variation in the 5'-flanking region of the $T G$ gene has been identified as having a significant association with the marbling score and is used in marker-assisted selection programs to improve the performance of intramuscular fat content in beef production (Barendse, 1999; Barendse et al., 2004; Burrell et al., 2004). However, other studies did not detect associations between the TG5 marker and fat deposition traits, or they obtained the opposite result (Casas et al., 2005; Rincker et al., 2006; Shin and Chung, 2007; Pannier et al., 2010).

The objectives of this study were to identify novel polymorphisms in the 5 '-flanking region of the $T G$ gene and to evaluate their effects on growth, carcass composition, and meat quality traits in Chinese beef cattle. The result of this study provides new evidence that single nucleotide polymorphisms (SNPs) in the 5'-flanking region of the $T G$ gene might be a useful marker with predictive merit for improving the beef production level.

\section{MATERIAL AND METHODS}

\section{Animals and carcass data}

A total of 237 animals including Simmental $(\mathrm{N}=71)$, Angus $(\mathrm{N}=42)$, Hereford $(\mathrm{N}=18)$, Charolais $(\mathrm{N}=29)$, Limousin $(\mathrm{N}=15)$, Qinchuan $(\mathrm{N}=20)$, Luxi $(\mathrm{N}=24)$, and Jinnan $(\mathrm{N}=18)$ were randomly selected from commercial populations and used in the association analysis. The animals were reared in the provinces of Inner Mongolia and Hebei. The animals (405 $\pm 50.5 \mathrm{~kg} ; 30 \pm 2$ months of age) were housed in a concrete-floored cowshed (in a single pen for each animal) and fed for 195 days. Carcass and meat quality traits were measured according to the criterion GB/T 17238-1998 Cutting Standard of Fresh and Chilled Beef in China (China Standard Publishing House). The following traits were measured or calculated: live weight (LW), carcass weight $(\mathrm{CW})$, dressing percentage (DP), meat weight (MW), meat percentage (MP), backfat thickness (BF), marbling score (MS), average daily gain (ADG), and loin muscle area (LMA). BF and LMA were 
measured between the 12th and 13th ribs. The MS for the quality grade was evaluated on a cross-section of the loin muscle between the 12th and 13th ribs, which is scored on a scale from 1 to 5 . All experimental procedures were performed according to authorization granted by the Chinese Ministry of Agriculture.

\section{Polymerase chain reaction (PCR) amplification and SNP genotyping}

DNA samples were extracted from blood samples according to Mullenbach et al. (1989), which were diluted to $50 \mathrm{ng} / \mu \mathrm{L}$ for PCR. According to the bovine $T G$ gene sequence that was cloned in our previous study (unpublished data), a pair of primers (5'-GGGGGATGA CTACGAGTATGAC-3' and 5'-AGCAGACCGAAGACCCATAG-3') was designed to amplify a 785-bp fragment (checked by DNA sequencing) within the 5 '-flanking region of the $T G$ gene. PCR amplifications were performed in $20-\mu \mathrm{L}$ volume containing $50 \mathrm{ng}$ DNA template, $10 \mathrm{pmol}$ of each primer, $0.20 \mathrm{mmol} \mathrm{dNTP}, 2.5 \mathrm{mmol} \mathrm{MgCl}_{2}$, and $0.5 \mathrm{U}$ Taq DNA polymerase (TaKaRa, Dalian, China). The PCR protocol was $94^{\circ} \mathrm{C}$ for $5 \mathrm{~min} ; 35$ cycles of $94^{\circ} \mathrm{C}$ for $30 \mathrm{~s}$, annealing for $30 \mathrm{~s}$, and $72^{\circ} \mathrm{C}$ for $30 \mathrm{~s}$; and a final extension at $72^{\circ} \mathrm{C}$ for $10 \mathrm{~min}$. The products were purified using Wizard Prep PCR purification kit (Shanghai Bioasia Biotechnology Co., Ltd., Shanghai, China) and sequenced in both directions (Beijing Aolaibo Biotechnology Co., Ltd., Beijing, China) using an Applied Biosystems 3730xl DNA sequencer (Foster City, CA, USA).

\section{Statistical analysis}

The association between SNP marker genotypes of the $T G$ gene and carcass and meat quality traits was analyzed by the least-squares method as applied in the general linear model procedure of SAS (SAS Institute Inc., Cary, NC, USA) according to the following statistical linear model:

$$
\mathrm{Y}_{\mathrm{ijk}}=\mu+\mathrm{BF}_{\mathrm{i}}+\text { Month }_{\mathrm{j}}+\mathrm{G}_{\mathrm{k}}+\mathrm{e}_{\mathrm{ijk}}
$$

where $Y_{i j k}$ indicates the observed value, $\mu$ is the overall mean for each trait, $B F_{i}$ is the effect of $\mathrm{i}^{\text {th }}$ breed and farm, Month ${ }_{j}$ is the effect of $\mathrm{j}^{\text {th }}$ month of slaughtering, $G_{k}$ is the $\mathrm{k}^{\text {th }}$ SNP marker genotype, and $e_{i j k}$ is the random error.

\section{RESULTS}

\section{Genotype patterns of different polymorphisms}

A 785-bp fragment of the 5'-flanking region of the $T G$ gene was amplified and sequenced successfully in 237 animals. The comparisons among these sequences revealed 4 mutations: T1355C, G1356A, T1531C, and C1548A (Figure 1).

The genotype frequencies of the 4 SNPs are shown in Table 1. The frequencies of the $\mathrm{CC}$ genotype of the T1355C polymorphism site, the AA genotype of the G1356A polymorphism site, the TT genotype of the T1531C polymorphism site, and the AA genotype of the C1548A polymorphism site were very low in most breeds. These genotypes were not detected in some breeds. Especially, the AA genotype of the C1548A polymorphism site was not detected in any of the 8 breeds. 


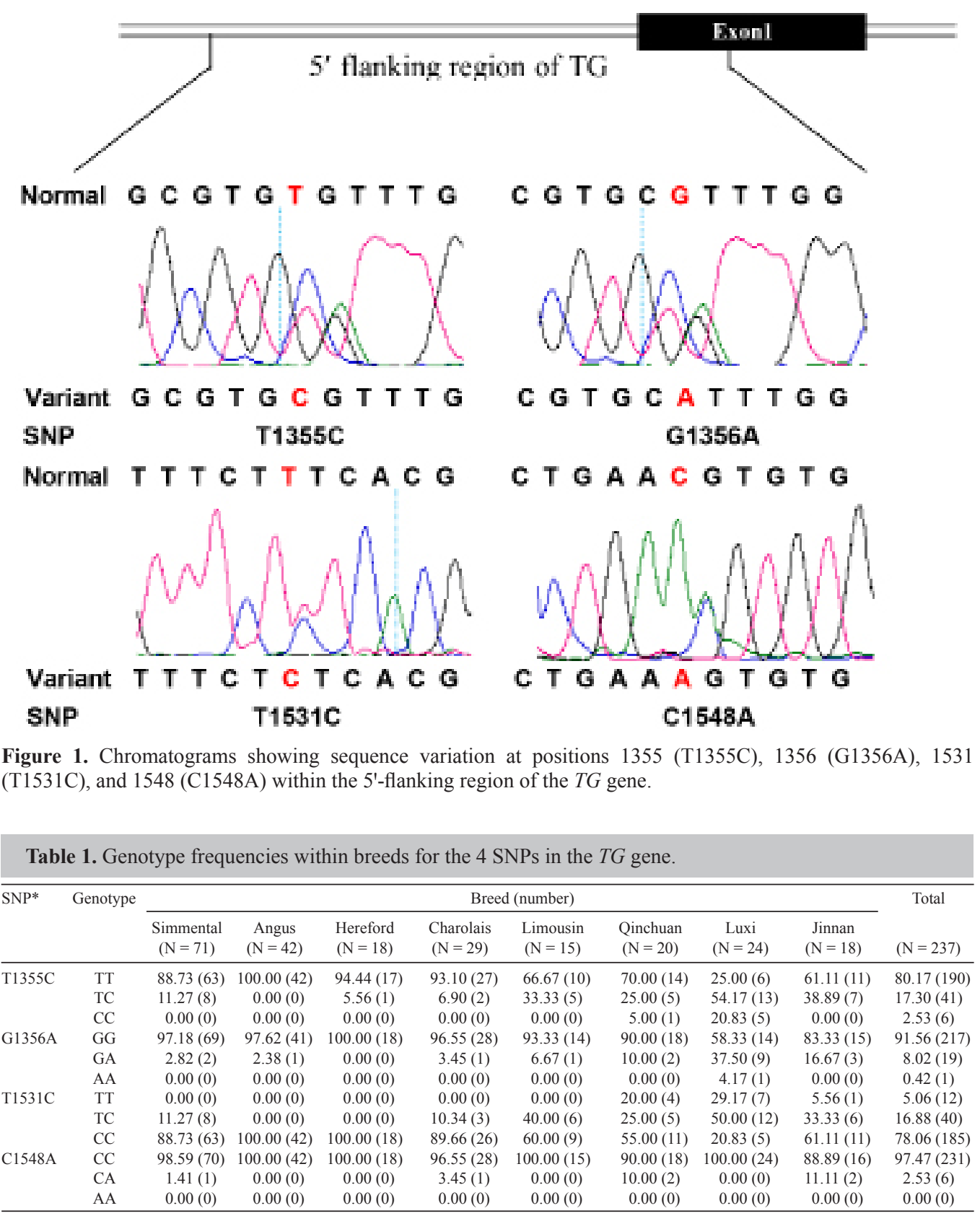

*Location of the SNP in the sequence M35823.

\section{SNP marker associations}

The relationships between the genotypes of 237 individuals and carcass and meat qual- 
ity traits were evaluated. The least-squares mean and standard error for each trait and the $T G$ genotype are given in Table 2. The gene-specific SNP marker association analysis indicated that T1355C was significantly associated with MP $(\mathrm{P}<0.05)$. Animals with the TC genotype have a higher MP than those with the TT genotype $(\mathrm{P}<0.05)$ (Table 2). Significant associations between the G1356A polymorphism and LW and LMA were also detected $(\mathrm{P}<0.05)$. Animals with the GG genotype have higher LW and LMA than those with the AA genotype $(\mathrm{P}<0.05)$ (Table 2). No significant association was observed between any of the marker genotypes and the other traits.

\begin{tabular}{|c|c|c|c|c|c|c|c|c|c|c|}
\hline \multirow[t]{2}{*}{ SNP } & \multirow[t]{2}{*}{ Genotype } & \multicolumn{9}{|c|}{ Traits (mean \pm standard error) } \\
\hline & & LW (kg) & $\mathrm{CW}(\mathrm{kg})$ & DP $(\%)$ & MW (kg) & MP (\%) & $\operatorname{LMA}\left(\mathrm{cm}^{2}\right)$ & $\mathrm{BF}(\mathrm{cm})$ & MS (1-5) & $\operatorname{ADG}(\mathrm{kg})$ \\
\hline \multirow[t]{4}{*}{ T1355C } & $\mathrm{TT}$ & $574.11 \pm 8.69$ & $318.00 \pm 5.85$ & $55.38 \pm 0.49$ & $259.67 \pm 4.66$ & $45.66 \pm 0.32^{\mathrm{a}}$ & $72.30 \pm 1.65$ & $1.13 \pm 0.07$ & $2.22 \pm 0.14$ & $0.59 \pm 0.03$ \\
\hline & $\mathrm{TC}$ & $564.94 \pm 12.68$ & $316.49 \pm 8.54$ & $56.11 \pm 0.71$ & $266.16 \pm 6.81$ & $46.72 \pm 0.47^{\mathrm{b}}$ & $70.09 \pm 2.41$ & $1.14 \pm 0.10$ & $2.41 \pm 0.21$ & $0.60 \pm 0.04$ \\
\hline & $\mathrm{CC}$ & $535.93 \pm 25.59$ & $300.38 \pm 17.24$ & $56.00 \pm 1.43$ & $249.91 \pm 13.74$ & $46.12 \pm 0.95^{\mathrm{ab}}$ & $66.30 \pm 4.87$ & $1.20 \pm 0.20$ & $2.11 \pm 0.43$ & $0.55 \pm 0.08$ \\
\hline & $P$ & 0.2861 & 0.5894 & 0.4883 & 0.3400 & $0.0374^{* *}$ & 0.3384 & 0.9283 & 0.5155 & 0.8559 \\
\hline \multirow[t]{4}{*}{ G1356A } & GG & $573.84 \pm 8.50^{\mathrm{a}}$ & $318.40 \pm 5.73$ & $55.49 \pm 0.48$ & $260.56 \pm 4.58$ & $45.77 \pm 0.32$ & $72.32 \pm 1.62^{\mathrm{a}}$ & $1.13 \pm 0.07$ & $2.22 \pm 0.14$ & $0.60 \pm 0.03$ \\
\hline & GA & $552.38 \pm 15.40^{\mathrm{a}}$ & $307.12 \pm 10.38$ & $55.60 \pm 0.87$ & $257.65 \pm 8.30$ & $46.35 \pm 0.58$ & $67.35 \pm 2.93^{\text {ab }}$ & $1.16 \pm 0.12$ & $2.28 \pm 0.26$ & $0.55 \pm 0.05$ \\
\hline & AA & $439.57 \pm 55.23^{b}$ & $237.29 \pm 37.24$ & $53.82 \pm 3.13$ & $191.97 \pm 29.76$ & $42.70 \pm 2.08$ & $48.56 \pm 10.50^{\mathrm{b}}$ & $0.69 \pm 0.44$ & $1.82 \pm 0.92$ & $0.23 \pm 0.18$ \\
\hline & $\mathrm{P}$ & $0.0241 * *$ & 0.0595 & 0.8489 & 0.0691 & 0.1576 & $0.0220^{* *}$ & 0.5495 & 0.7069 & 0.0911 \\
\hline \multirow[t]{4}{*}{$\mathrm{T} 1531 \mathrm{C}$} & TT & $547.87 \pm 19.13$ & $303.97 \pm 12.86$ & $55.40 \pm 1.07$ & $252.40 \pm 10.24$ & $45.82 \pm 0.72$ & $67.09 \pm 3.64$ & $1.02 \pm 0.15$ & $2.45 \pm 0.32$ & $0.60 \pm 0.06$ \\
\hline & $\mathrm{CT}$ & $574.30 \pm 12.57$ & $320.03 \pm 8.45$ & $55.75 \pm 0.70$ & $267.35 \pm 6.72$ & $46.15 \pm 0.47$ & $70.90 \pm 2.39$ & $1.18 \pm 0.10$ & $2.24 \pm 0.21$ & $0.61 \pm 0.04$ \\
\hline & $\mathrm{CC}$ & $572.85 \pm 8.75$ & $317.69 \pm 5.88$ & $55.46 \pm 0.49$ & $259.56 \pm 4.68$ & $45.76 \pm 0.33$ & $72.30 \pm 1.66$ & $1.13 \pm 0.07$ & $2.22 \pm 0.14$ & $0.59 \pm 0.03$ \\
\hline & $\mathrm{P}$ & 0.3546 & 0.4427 & 0.8757 & 0.2161 & 0.6375 & 0.3342 & 0.5623 & 0.7626 & 0.7341 \\
\hline \multirow[t]{4}{*}{ C1548A } & $\mathrm{CC}$ & $571.15 \pm 8.51$ & $317.00 \pm 5.72$ & $55.50 \pm 0.47$ & $260.16 \pm 4.57$ & $45.8 \pm 0.32$ & $71.81 \pm 1.62$ & $1.13 \pm 0.07$ & $2.24 \pm 0.14$ & $0.59 \pm 0.03$ \\
\hline & $\mathrm{CA}$ & $586.70 \pm 24.34$ & $323.30 \pm 16.35$ & $55.14 \pm 1.36$ & $258.92 \pm 13.06$ & $44.87 \pm 0.91$ & $70.34 \pm 4.63$ & $1.08 \pm 0.19$ & $2.14 \pm 0.40$ & $0.64 \pm 0.08$ \\
\hline & AA & - & - & - & - & - & - & - & - & - \\
\hline & $\mathrm{P}$ & 0.5044 & 0.6875 & 0.7793 & 0.9210 & 0.2648 & 0.7398 & 0.7644 & 0.7962 & 0.4849 \\
\hline
\end{tabular}

$\mathrm{LW}=$ live weight; $\mathrm{CW}=$ carcass weight; $\mathrm{DP}=$ dressing percentage; $\mathrm{MW}=$ meat weight; $\mathrm{MP}=$ meat percentage; $\mathrm{LMA}=$ loin muscle area; $\mathrm{BF}=$ backfat thickness; $\mathrm{MS}=$ marbling score; ADG = average daily gain. **Effect was significant at $\mathrm{P}<0.05$. ${ }^{\mathrm{a}, \mathrm{b}} \mathrm{Means}$ of traits with different superscripts were significantly different.

\section{DISCUSSION}

A QTL with an effect on fat deposition has been mapped to the centromeric region of Bos taurus chromosome 14 (Casas et al., 2000). The $T G$ gene is proposed to be a positional and functional candidate gene for this QTL because it could affect lipid metabolism by its iodide products T3 and T4 (Barendse, 1999). The TG5 SNP has been reported to have a significant association with fat deposition and could be used as a molecular marker for marbling deposition in beef cattle (Barendse, 1999; Grisart et al., 2002). Because of its predictive merit, many TG5 marker studies have been carried out by different researchers in various populations, and the results varied. Some studies obtained consistent or similar results with Barendse (1999). A significant association was found between intramuscular fat (IMF) in the musculus longissimus dorsi of German Holstein and Wagyu (Mears et al., 2001; Thaller et al., 2003). Similarly, Burrell et al. (2004) reported that the TT genotype was associated with a higher level of marbling than the CC and CT genotypes in beef cattle. Anton et al. (2008) also reported the association between TG5 and IMF in a small population that consisted of Red Angus, Charolais, Limousin, and Hungarian Fleckvieh breeds. Nevertheless, the other studies did not detect the associations between the TG5 marker and the fat deposition traits, or they obtained the opposite result. Casas et al. (2005) reported that the marker was associated with fat thickness and LMA, but it was not associated with MS in Brahman cattle. No significant association was detected between the TG5 marker and IMF in Irish cattle and 
American Simmental (Rincker et al., 2006; Pannier et al., 2010). In Korean cattle, an association between TG5 and MS was detected, but the CC and CT genotypes were associated with a higher MS than the TT genotype (Shin and Chung, 2007). These inconsistent results may be attributed to the different genetic backgrounds of the populations that were studied and the different models that were used. Furthermore, quantitative traits such as meat quality traits are regulated by multiple genes. Thus, a candidate gene with an effect on a trait in one population may have no effect or a negative effect in another population.

Because of the limitation of the TG5 marker in evaluating the IMF traits, several studies developed new SNP markers in the $T G$ gene. Five novel SNPs in the $T G$ gene introns were identified, and no association was detected between these SNPs and IMF in the population GPE7, which consisted of Angus, Simmental, Gelbvieh, Hereford, Limousin, and Charolais (Casas et al., 2007). Gan et al. (2008) and Hou et al. (2011) developed a series of SNPs in the 3'-flanking region. Two groups of 4 linked SNPs were identified to have significant associations with MS. However, these results need to be verified in other populations.

Although the $T G$ gene is located in the region of the QTL for fat thickness, USDA yield grade, post-weaning average daily gain, birth weight, and weaning weight traits (Casas et al., 2003; Thaller et al., 2003; Kneeland et al., 2004; Maltecca et al., 2009; McClure et al., 2010), most studies focus on the IMF deposition. Besides IMF, the $T G$ gene was reported to be associated with ADG, retail product yield, fat yield, bone yield, fat thickness, and LMA (Moore et al., 2003; Casas et al., 2005, 2007).

In this study, we identified 4 SNPs in the 5'-flanking region of the $T G$ gene by sequencing, and we evaluated their effects on carcass and meat quality traits in Chinese steers. There was not a significant association between the 4 SNPs and MS. However, we found that $\mathrm{T} 1355 \mathrm{C}$ had a significant association with MP, and G1356A had a significant association with LW and LMA. These results were consistent with or similar to those of previous studies (Casas et al., 2005, 2007). Besides MP, there were no other related traits that were associated with the $\mathrm{T} 1355 \mathrm{C}$ polymorphism. Therefore, the T1355C polymorphism should be evaluated in a large population. The G1356A site also showed an association trend with $\mathrm{CW}(\mathrm{P}=0.0595), \mathrm{MW}(\mathrm{P}$ $=0.0691)$, and $\mathrm{ADG}(\mathrm{P}=0.0911)$ in addition to LW and LMA.

In conclusion, our results provide evidence that the SNPs in the 5'-flanking region of the $T G$ gene has potential effects on carcass or growth traits such as LW and LMA. However, further study will be necessary to test these SNPs in a larger population and to investigate whether the $T G$ gene plays a role in cattle growth or carcass traits.

\section{ACKNOWLEDGMENTS}

Research supported by the Chinese National Programs for High Technology Research and Development (\#2013AA102505-4), the National Natural Science Foundation of China (\#31201782), the Agricultural Science and Technology Innovation Program (\#ASTIP-IAS03), and Twelfth "Five-Year" National Science and Technology Support Project (\#2011BAD28B04).

\section{REFERENCES}

Ailhaud G, Grimaldi P and Negrel R (1992). Cellular and molecular aspects of adipose tissue development. Anпи. Rev. Nutr. 12: 207-233. 
Anton I, Kovacs K, Fesus L, Varhegyi J, et al. (2008). Effect of DGAT1 and TG gene polymorphisms on intramuscular fat and on milk production traits in different cattle breeds in Hungary. Acta Vet. Hung. 56: 181-186.

Barendse W, Bunch R, Thomas M and Armitage S (2004). The TG5 thyroglobulin gene test for a marbling quantitative trait loci evaluated in feedlot cattle. Aust. J. Exp. Agric. 44: 669-674.

Barendse WJ (1999). Assessing Lipid Metabolism. International Patent Application WO9923248 US6383751 (PCT/ AU98/00882). Available at: [http://ep.espacenet.com].

Burrell DN, Moser GHD, Hetzel J and Mizoguchi YSS (2004). Meta Analysis Confirms Associations of the TG5 Thyroglobulin Polymorphism with Marbling in Beef Cattle. 29th International Conference on Animal Genetics, ISAG, Tokyo.

Casas E, Shackelford SD, Keele JW, Stone RT, et al. (2000). Quantitative trait loci affecting growth and carcass composition of cattle segregating alternate forms of myostatin. J. Anim. Sci. 78: 560-569.

Casas E, Shackelford SD, Keele JW, Koohmaraie M, et al. (2003). Detection of quantitative trait loci for growth and carcass composition in cattle. J. Anim. Sci. 81: 2976-2983.

Casas E, White SN, Riley DG, Smith TP, et al. (2005). Assessment of single nucleotide polymorphisms in genes residing on chromosomes 14 and 29 for association with carcass composition traits in Bos indicus cattle. J. Anim. Sci. 83: 13-19.

Casas E, White SN, Shackelford SD, Wheeler TL, et al. (2007). Assessing the association of single nucleotide polymorphisms at the thyroglobulin gene with carcass traits in beef cattle. J. Anim. Sci. 85: 2807-2814.

Darimont C, Gaillard D, Ailhaud G and Negrel R (1993). Terminal differentiation of mouse preadipocyte cells: adipogenic and antimitogenic role of triiodothyronine. Mol. Cell Endocrinol. 98: 67-73.

Gan QF, Zhang LP, Li JY, Hou GY, et al. (2008). Association analysis of thyroglobulin gene variants with carcass and meat quality traits in beef cattle. J. Appl. Genet. 49: 251-255.

Grisart B, Coppieters W, Farnir F, Karim L, et al. (2002). Positional candidate cloning of a QTL in dairy cattle: identification of a missense mutation in the bovine DGAT1 gene with major effect on milk yield and composition. Genome Res. 12: $222-231$.

Hou GY, Yuan ZR, Zhou HL, Zhang LP, et al. (2011). Association of thyroglobulin gene variants with carcass and meat quality traits in beef cattle. Mol. Biol. Rep. 38: 4705-4708.

Kneeland J, Li C, Basarab J, Snelling WM, et al. (2004). Identification and fine mapping of quantitative trait loci for growth traits on bovine chromosomes 2, 6, 14, 19, 21, and 23 within one commercial line of Bos taurus. J. Anim. Sci. 82: 3405-3414.

Maltecca C, Weigel KA, Khatib H, Cowan M, et al. (2009). Whole-genome scan for quantitative trait loci associated with birth weight, gestation length and passive immune transfer in a Holstein x Jersey crossbred population. Anim. Genet. 40: 27-34.

McClure MC, Morsci NS, Schnabel RD, Kim JW, et al. (2010). A genome scan for quantitative trait loci influencing carcass, post-natal growth and reproductive traits in commercial Angus cattle. Anim. Genet. 41: 597-607.

Mears GJ, Mir PS and Bailey DRC (2001). Effect of Wagyu genetics on marbling, backfat and circulating hormones in cattle. Can. J. Anim. Sci. 81: 65-73.

Moore SS, Li C, Basarab J, Snelling WM, et al. (2003). Fine mapping of quantitative trait loci and assessment of positional candidate genes for backfat on bovine chromosome 14 in a commercial line of Bos taurus. J. Anim. Sci. 81: 19191925.

Mullenbach R, Lagoda PJ and Welter C (1989). An efficient salt-chloroform extraction of DNA from blood and tissues. Trends Genet. 5: 391.

Pannier L, Mullen AM, Hamill RM, Stapleton PC, et al. (2010). Association analysis of single nucleotide polymorphisms in DGAT1, TG and FABP4 genes and intramuscular fat in crossbred Bos taurus cattle. Meat Sci. 85: 515-518.

Rincker CB, Pyatt NA, Berger LL and Faulkner DB (2006). Relationship among GeneSTAR marbling marker, intramuscular fat deposition, and expected progeny differences in early weaned Simmental steers. J. Anim. Sci. 84: 686-693.

Shin SC and Chung ER (2007). Association of SNP marker in the thyroglobulin gene with carcass and meat quality traits in Korean cattle. Asian Aust. J. Anim. Sci. 20: 172-177.

Smas CM and Sul HS (1995). Control of adipocyte differentiation. Biochem. J. 309 (Pt 3): 697-710.

Thaller G, Kuhn C, Winter A, Ewald G, et al. (2003). DGAT1, a new positional and functional candidate gene for intramuscular fat deposition in cattle. Anim. Genet. 34: 354-357. 